\title{
PROSES BERPIKIR SISWA KELAS VII SMP NEGERI 2 SEMEN KEDIRI BERDASARKAN TAHAP PROSES BERPIKIR SOLSO DALAM MEMECAHKAN MASALAH MATEMATIKA DITINJAU DARI ADVERSITY QUOTIENT (AQ)
}

\author{
Anis Hanafiah ${ }^{1}$, Riyadi ${ }^{2}$, Imam Sujadi ${ }^{3}$ \\ ${ }^{1,2,3}$ Prodi Magister Pendidikan Matematika, FKIP Universitas Sebelas Maret Surakarta
}

\begin{abstract}
The purposes of the research were to describe (1) Thinking process of climber students grade VII SMPN 2 Semen in problem solving of mathematics. (2) Thinking process of camper students grade VII SMPN 2 Semen in problem solving of mathematics (3) Thinking process of quitter students grade VII SMPN 2 Semen in problem solving of mathematics. The thinking process in this research uses steps of Solso thinking, forming concept, logically, and taking decision. This research is qualitative descriptive research. The subjects in this research are taken by purposive sampling. The subjects of this research are 3 students from grade VII SMPN 2 Semen, they are 1 student of climber type, 1 student of campers type, and 1 student of quitters type. The data collection of this research uses polling and questionaire technic based on duties that is done for comparison material. The legality of data used in this research is triangulation time and using reference sufficience. The technic of data analysis used is Miles and Huberman concept, these are data reduction, giving data and getting conclution. The results of this research show that (1) the thinking process of climber students, in problem solving of mathematics on steps: (a) understanding the problem that have done: (i) forming concept, (ii) thinking logically, (iii) taking decision; (b) arranging the plan for problem solving by: (i) forming concept, (ii) thinking logically, (iii) taking decision. (c) doing the plan of problem solving by: (i) forming concept, (ii) thinking logically, (iii) taking decision. (d) recheck the result by: (i) forming concept, (ii) thinking logically, (iii) taking decision; (2) The thinking process of camper students in problem solving of mathematics on steps: (a) understanding the problem by: (i) forming concept, (ii) thinking logically, (iii) taking decision. (b) arranging the plan for problem solving by: (i) forming concept, (ii) thinking logically, (iii) not taking decision. (c) doing the plan for problem solving, by (i) forming concept, (ii) thinking logically, (iii) taking decision. (d) recheck the result by: (i) forming concept, (ii) thinking logically, (iii) not taking decision. (3) The thinking process of quitter students in problem solving of mathematics on steps: (a) understanding the problem by, (i) forming concept, (ii) not thinking logically, (iii) can't take decision. (b) planning for problem soving: (i) not forming concept, (ii) thinking logically, (iii) can't take decision, (c) can't run for the probem solving. (d) not rechecking the problem solving. Keywords: thinking process, problem solving, Adversity Quotient (AQ)
\end{abstract}

\section{PENDAHULUAN}

Kegiatan pembelajaran matematika selalu terkait dengan suatu masalah dan salah satu aktifitas terpenting dalam kegiatan pembelajaran matematika adalah memecahkan masalah. Pemberian masalah terutama selama proses pembelajaran berlangsung, berarti memberikan kesempatan pada siswa untuk membangun konsep matematika dan mengembangkan keterampilan matematikanya. Pemahaman konsep dan keterampilan yang tinggi dalam menggeneralisasikan pengetahuan tersebut dalam pemecahan sebuah masalah matematika akan meningkatkan kemampuan matematika. Kemampuan matematika yang baik dapat membantu siswa untuk memecahkan berbagai 
permasalahan matematika dalam pembelajaran maupun aplikasinya dalam kehidupan nyata.

Ide mengenai pemecahan masalah salah satunya dikemukakan oleh Polya. Polya (dalam Ruseffendi, 1988) mengembangkan empat langkah pemecahan masalah yaitu memahami masalah atau persoalan (understand the problem), menyusun rencana pemecahan masalah (make a plan), melaksanakan rencana pemecahan (carry out a plan), memeriksa kembali hasil pemecahan (look back at the completed solution). Dengan menggunakan langkah-langkah pemecahan masalah oleh Polya diharapkan siswa dapat lebih runtut dan terstruktur dalam memecahkan masalah.

Proses berpikir terjadi dalam benak siswa ketika memecahkan masalah, hingga dapat menemukan pemecahan masalah matematika. Herman (2005) menyatakan, dengan pemecahan masalah, siswa akan berlatih memproses data atau informasi. Pemrosesan data dan informasi inilah yang disebut berpikir. Sementara itu Yulaelawati (dalam Muhtarom, 2012) mengatakan, salah satu peran guru dalam pembelajaran matematika adalah membantu siswa mengungkapkan bagaimana proses yang berjalan dalam pikirannya ketika memecahkan masalah, misalnya dengan cara meminta siswa menceritakan langkah yang ada dalam pikirannya. Hal ini diperlukan untuk mengetahui kesalahan berpikir yang terjadi dan merapikan jaringan pengetahuan siswa. Bagi siswa, mengungkapkan proses berpikir tidaklah mudah. Perlu motivasi, positive thinking, kepercayaan diri, dan kemampuan komunikasi yang baik. Sebagaimana diungkapkan dalam penelitian Callejo, et. al. (2009) bahwa sikap percaya diri dapat menumbuhkan motivasi untuk dapat memecahkan masalah matematika.

Menurut Tatag (2007), proses berpikir adalah suatu proses yang dimulai dengan menerima data, mengolah dan menyimpannya dalam ingatan serta selanjutnya mengambil kembali ingatan saat dibutuhkan untuk pengolahan selanjutnya. Solso (2007:402), berpendapat, dalam memecahkan suatu masalah terdapat 3 tahap proses berpikir, yaitu: pembentukan konsep, logika, dan pengambilan keputusan.

Menurut Solso, pembentukan konsep berhubungan dengan pengasahan sifat-sifat yang sesuai dengan kelas objek atau ide. Pembentukan konsep juga berhubungan dengan bentuk visual, prototype dan satuan semantik. Bagian pembentukan konsep yang paling luar biasa adalah memspesifikasikan komponen atau ciri-ciri dari konsep dan bagaimana konsep terstruktur dalam jaringan semantik. Berpikir adalah proses umum untuk menentukan sebuah isu dalam berpikiran, sementara logika adalah ilmu berpikir. Keputusan merupakan sebuah kesimpulan yang biasanya dinyatakan secara implisit atau eksplisit dalam konteks pernyataan kemungkinan. Dalam penalaran induktif keputusan 
diambil berdasarkan pengalaman masa lalu dan kesimpulannya berdasarkan yang dirasa sebagai pilihan terbaik dari sejumlah alternatif.

Mengetahui proses berpikir siswa dalam memecahkan suatu masalah matematika sangat penting bagi guru. Dengan mengetahui proses berpikir siswa, membantu guru mendeteksi kesulitan siswa, guru dapat melacak letak dan jenis kesalahan yang dilakukan oleh siswa dalam proses pemecahan masalah. Kesalahan yang dilakukan siswa dapat menjadi sumber informasi bagi guru untuk menentukan penyebab kesulitan siswa, kemudian hal tersebut menjadi bahan kajian bagi guru untuk memperbaiki teknis pembelajarannya, memberikan penekanan serta evaluasi pada tahap pembelajaran yang dapat menjadi penyebab kesulitan siswa. Selanjutnya proses berpikir siswa dapat menjadi acuan bagi guru untuk menentukan metode pembelajaran yang tepat bagi siswa.

Kemampuan matematika siswa dalam pemecahan masalah dapat dilihat melalui proses berpikirnya. Melalui proses berpikir dapat diketahui tentang tingkat pemahaman konsep yang telah disampaikan, algoritma perhitungan yang benar, hingga tahap-tahap proses pemecahan masalah. Sebagaimana disebutkan dalam kurikulum 2013 bahwa tujuan pembelajaran matematika adalah menjadikan siswa memiliki kemampuan pikir dan tindak yang efektif dan kreatif dalam ranah abstrak dan konkret sesuai dengan yang dipelajari disekolah dan sumber lain sejenis. Untuk mewujudkan tindak yang efektif dan kreatif siswa terutama dalam pemecahan masalah matematika diperlukan kemampuan berpikir yang baik, dan hal tersebut dapat dicapai bila proses berpikirnya dalam pemecahan masalah matematika juga baik.

Pehkonen (2000:52) mendefinisikan, pemecahan masalah secara umum diterima sebagai alat untuk memajukan ketrampilan dalam berpikir dan memecahkan masalah yang tidak hanya bertujuan dalam pembelajaran matematika, tetapi juga merupakan sarana utama untuk pelajaran yang lain atau kegiatan yang lain. Dan sebagaimana diketahui bahwa kemampuan memecahkan masalah matematika dipengaruhi oleh dua faktor, yaitu faktor langsung dan faktor tak langsung. Faktor langsung adalah faktor yang mempengaruhi secara langsung kemampuan pemecahan masalah. Diantaranya adalah dukungan, kelengkapan fasilitas belajar dan ketersediaan sumber belajar. Sedangkan beberapa hal yang merupakan faktor tak langsung adalah motivasi, kemampuan/kompetensi diri, serta kecerdasan individu dalam menyikapi suatu masalah, kemampuannya dalam merubah masalah/hambatan menjadi sebuah tantangan menarik yang dapat menumbuhkan rasa penasaran untuk segera diselesaikan. Kecerdasan menjadikan semua permasalahan yang dihadapi sebagai suatu prestasi yang harus diraih sebagai sebuah pengakuan akan kompetensi diri yang dimiliki, yang disebut kecerdasan Adversity Quotient (AQ). Sikap dan kecerdasan tersebut merupakan faktor terpenting 
untuk meningkatkan kemampuan memecahkan masalah matematika. Pernyataan ini didukung oleh hasil penelitian yang telah dilakukan oleh Huijuan (2009) yang menyatakan bahwa terdapat hubungan yang signifikan antara Adversity Quotient (AQ) dengan prestasi akademik mahasiswa St. Yoseph Quezon City.

Terkait hal tersebut, Stoltz (2000: 9) mengungkapkan, Adversity Quotient sebagai kecerdasan seseorang dalam menghadapi rintangan atau kesulitan secara teratur. Adversity Quotient membantu individu memperkuat kemampuan dan ketekunan dalam menghadapi tantangan hidup sehari-hari seraya tetap berpegang teguh pada prinsip dan impian tanpa memperdulikan apa yang sedang terjadi. Masih menurut Stoltz (2000: 12), kesuksesan seseorang dalam menjalani kehidupan terutama ditentukan oleh tingkat Adversity Quotient. Untuk meningkatkan intuisi siswa dalam memecahkan masalah matematika maka AQ harus ditingkatkan pula agar siswa memiliki keuletan dalam mengeksplorasi potensi yang dimilikinya secara optimal.

Didalam merespon suatu kesulitan terdapat tiga kelompok tipe manusia ditinjau dari tingkat kemampuannya Stolz (2000: 18) yaitu: (1) Quitters (mereka yang berhenti) adalah seseorang yang memilih untuk keluar, menghindari kewajiban, mundur dan berhenti apabila menghadapi kesulitan. (2) Campers atau satis-ficer (dari kata satisfied = puas dan suffice $=$ mencukupi) . Golongan ini puas dengan mencukupkan diri dan tidak mau mengembangkan diri. (3) Climbers (pendaki) yaitu mereka yang selalu optimis, melihat peluang-peluang, melihat celah, melihat senoktah harapan di balik keputusasaan, selalu bergairah untuk maju. Nokta kecil yang dianggap sepele, bagi para Climbers mampu dijadikannya sebagai cahaya pencerah kesuksesan (Ginanjar Ary Agustian, 2001: 17).

Proses berpikir siswa dalam memecahkan masalah matematika sangat berkaitan dengan tingkat kecerdasan adversitas yang dimiliki siswa. Siswa dengan tipe AQ yang berbeda tentunya juga akan berbeda dalam proses berpikirnya. Hal ini dikarenakan kecerdasan adversitas yang dimiliki seorang siswa menunjukkan kemampuan siswa tersebut dalam menghadapi kesulitan. Sebagaimana diungkapkan Siti Nureini (2011) dalam salah satu hasil penelitiannya bahwa prestasi belajar matematika siswa kelompok climbers lebih baik dibandingkan kelompok campers dan kelompok quitters, sedangkan prestasi belajar matematika siswa kelompok campers sama dengan kelompok quitters. Dari penjelasan tersebut, kemampuan proses berpikir siswa sangat dipengaruhi oleh tingkat kecerdasan adversitasnya (Adversity Quotient/AQ).

Berdasar pada kenyataan bahwa kemampuan proses berpikir siswa sangat dipengaruhi oleh tingkat kecerdasan adversitasnya (AQ) maka dilakukan observasi untuk 
mendapatkan tiga kelompok tingkat kecerdasan, yaitu siswa dengan tipe quitter (AQ rendah), tipe camper (AQ sedang), dan tipe climber (AQ tinggi).

Untuk mengetahui lebih jauh mengenai hubungan antara tipe AQ dengan proses berpikir (pembentukan konsep, logika, pengambilan keputusan) siswa dalam memecahkan masalah matematika khususnya perbandingan maka, peneliti melakukan penelitian pada siswa kelas VII SMP Negeri 2 Semen tahun pelajaran 2014/2015.

\section{METODE PENELITIAN}

Penelitian ini dilakukan di SMP Negeri 2 Semen Kabupaten Kediri, pada semester ganjil tahun ajaran 2014-2015. Subjek penelitian ini adalah siswa kelas VII SMP Negeri 2 Semen Kabupaten Kediri tahun ajaran 2014-2015 semester ganjil yang telah menerima materi perbandingan. Teknik pemilihan subjek penelitian menggunakan purposive sampling yaitu suatu cara pengambilan informan sumber data dengan pertimbangan tertentu. Berdasarkan hasil konsultasi dengan guru matematika didapatkan siswa yang memenuhi kriteria sebagai subjek penelitian sebanyak tiga siswa yaitu satu siswa pada masing-masing kategori kecerdasan. Instrumen utama penelitian adalah peneliti sendiri sebagai pewawancara yang dibantu dengan instrumen bantu berupa soal tes pemecahan masalah dan pedoman wawancara. Validitas data dalam penelitian ini dilakukan dengan triangulasi waktu dan meningkatkan ketekunan.

Data dalam penelitian ini adalah hasil angket Adversity Quotient $(A Q)$ siswa yang tergolong dalam tiga tingkat kecerdasan, yaitu tinggi (climber), sedang (camper), dan rendah (quitter). Adapun sumber data pada penelitian ini diperoleh dari hasil pekerjaan subjek, wawancara dengan subjek dan catatan lapangan. Teknik pengumpulan data dalam penelitian ini adalah wawancara berbasis tugas. Adapun teknik analisis data yang dilakukan dalam penenlitian ini meliputi: 1) membuat transkrip data verbal dari hasil rekaman (digunakan alat bantu perekam suara); 2) menelaah seluruh data dari sumber yaitu hasil pekerjaan subjek, hasil wawancara, dan catatan lapangan; 3) melakukan reduksi data (reduksi data hasil wawancara berbasis tugas, catatan lapangan, dan hasil pekerjaan subjek); 4) menyusun satuan-satuan analisis data dan melakukan pengkodean; 5) menganalisis dan menggambarkan proses berpikir siswa dalam pemecahan masalah; 6) melakukan penafsiran data; 7) melakukan triangulasi terhadap data pertama dan data kedua untuk mendapatkan data yang valid, data yang sudah valid tersebut dikelompokkan berdasarkan kecerdasan adversitas siswa climber, camper, dan quitter dalam pemecahan masalah matematika; dan 8) menulis laporan hasil penelitian. 


\section{HASIL PENELITIAN DAN PEMBAHASAN}

Data penelitian yang dikumpulkan adalah proses berpikir siswa yang diperoleh dari wawancara berbasis tugas pemecahan masalah. Tugas berupa tes pemecahan masalah yang terkait dengan materi perbandingan yang diberikan kepada subjek. Hasil pekerjaan subjek dijadikan sebagai dasar wawancara berbasis tugas, kemudian dianalisis sehingga diperoleh kesimpulan semesntara proses berpikir siswa. Pada waktu yang berbeda, subjek diberi tes pemecahan masalah yang dilanjutkan dengan wawancara berbasis tugas, data kemudian dianalisis dan dilakukan triangulasi untuk mengelompokkan data sesuai langkah-langkah pemecahan masalah Polya.

Hasil penelitian ini sebagai berikut:

\section{Proses berpikir siswa climber kelas VII SMPN 2 Semen dalam memecahkan masalah perbandingan.}

Pada langkah memahami masalah, siswa melakukan pembentukan konsep yaitu dengan menyebutkan informasi yang terdapat pada soal, selain itu siswa juga menyebutkan hal-hal yang diketahui maupun ditanyakan. Siswa juga melakukan proses berpikir logika yang ditunjukkan aktivitas berpikirnya dalam menentukan konsep yang terkait dengan permasalahan, mereka berusaha mengkaitkan hal-hal yang diketahui dengan ilmu pengetahuan yang telah dimiliki. Selain itu, siswa climber melakukan proses berpikir mengambil keputusan dengan menyebutkan alasan dari pemilihan konsep yang terkait dengan permasalahan. Alasan atau argumentasi yang diberikan tersebut menunjukkan keyakinan siswa climber akan kebenaran keputusannya.

Pada langkah menyusun rencana pemecahan masalah, siswa climber melakukan proses berpikir membentuk konsep, yang ditunjukkan siswa dengan menyebutkan hal yang akan dilakukannya atau digunakannya untuk menyelesaikan permasalahan. Mereka juga berpikir logika, hal ini diketahui saat mereka menyatakan bahwa hal-hal yang diketahui dalam soal telah cukup untuk menyelesaikan permasalahan. Hasil pemikiran mereka tersebut merupakan wujud integrasi ilmu pengetahuan yang dimiliki. Pada langkah ini, mereka juga telah mengambil keputusan yang ditunjukkan dengan kemampuannya dalam menyusun rencana atau langkah-langkah penyelesaian masalah.

Langkah pemecahan masalah berikutnya adalah melaksanakan rencana pemecahan masalah. Pada langkah ini siswa juga telah melakukan 3 tahap proses berpikir. Yang pertama adalah membentuk konsep. Aktivitas proses berpikir siswa ini ditunjukkan siswa dengan kemampuannya menempatkan/mensubstitusikan nilai-nilai yang diketahui ke dalam aturan/konsep yang telah ditentukan berupa sebuah model matematika. Mereka juga telah melakukan proses berpikir logika, hal ini dapat dilihat pada saat siswa menggunakan model matematika yang telah dibuatnya untuk 
menjalankan rencana pemecahan masalah, selain itu siswa juga mengintegrasikan ilmu pengetahuan yang telah dimiliki dalam proses pemecahan masalah hingga menemukan hasilnya. Dan pada tahap pengambilan keputusan, siswa membuat kesimpulan yang tepat dari hasil pemecahan masalah yang telah dilakukan.

Langkah pemecahan masalah selanjutnya adalah memeriksa kembali jawaban dalam hal ini adalah pemecahan masalah. Pada langkah ini siswa melakukan pembentukan konsep dengan menganggap perlu untuk memeriksa kembali kebenaran penyelesaian masalah yang telah ditentukan. Mereka juga berpikir logika, dengan memeriksa kembali jawaban yaitu melakukan pengecekan pada setiap tahap proses pemecahan masalah termasuk kesimpulan. Dan yang terakhir siswa melakukan pengambilan keputusan dengan meyakini kebenaran kesimpulan yang dibuatnya.

\section{Proses berpikir siswa camper kelas VII SMPN 2 Semen dalam memecahkan masalah perbandingan.}

Pada langkah memahami masalah, siswa melakukan tahap proses berpikir pembentukan konsep. Hal ini ditunjukkan dengan kemampuannya menyebutkan informasi yang terdapat dalam soal. Selain itu, siswa juga dapat mengidentifikasi masalah dengan menyebutkan hal-hal yang diketahui maupun ditanyakan. Pada tahap proses berpikir logika, siswa mengkaitkan hal-hal yang diketahui dalam permasalahan dengan ilmu pengetahuan yang telah dimiliki sehingga dapat menentukan konsep yang terkait dengan permasalahan. Dan pada tahap pengambilan keputusan, ditunjukkan dengan siswa mengemukakan alasannya dalam menentukan konsep yang tepat terkait dengan permasalahan, sebagai penegasan bahwa mereka mengambil keputusan yang benar.

Langkah pemecahan masalah berikutnya adalah menyusun rencana pemecahan masalah. Pada langkah ini siswa melakukan tahap proses berpikir pembentukan konsep, yaitu dengan menyebutkan hal-hal yang akan dilakukannya atau digunakannya untuk menyelesaikan masalah. Selanjutnya siswa juga berpikir logika yaitu dengan mengintegrasikan ilmu pengetahuan yang dimiliki sehingga mereka mampu menentukan bahwa hal-hal yang diketahui dalam permasalahan telah cukup untuk menyelesaikan permasalahan tersebut. Akan tetapi, mereka tidak dapat mengambil keputusan karena tidak menyusun rencana atau langkah-langkah penyelesaian masalah.

Langkah pemecahan masalah selanjutnya adalah menjalankan rencana pemecahan masalah. Pada langkah ini siswa melakukan proses berpikir pembentukan konsep. Hal ini ditunjukkan dengan kemampuan siswa menempatkan atau mensubstitusikan nilai-nilai yang diketahui dalam aturan konsep yang telah ditentukan, yaitu berupa model matematika. Pada tahap proses berpikir logika, siswa menyelesaikan permasalahan dengan mengintegrasikan ilmu pengetahuan yang dimiliki ke dalamnya. 
Sedangkan pada tahap pengambilan keputusan, siswa menemukan atau menentukan hasil pemecahan masalah serta membuat kesimpulan dari hasil pemecahan tersebut.

Langkah pemecahan masalah yang terakhir adalah memeriksa kembali pemecahan masalah. Pada langkah ini, siswa melakukan proses berpikir pembentukan konsep yaitu dengan memandang perlu untuk memeriksa kembali proses penyelesaian masalah. Proses berpikir logika siswa ditunjukkan dengan memeriksa kembali jawaban yaitu dengan melakukan pengecekan setiap tahap proses pemecahan masalah. Namun, pada tahap proses berpikir selanjutnya, siswa tidak mengambil keputusan karena tidak yakin dengan kebenaran kesimpulan yang telah dibuat.

\section{Proses berpikir siswa quitter kelas VII SMPN 2 Semen dalam memecahkan masalah perbandingan.}

Pada langkah memahami masalah, siswa melakukan proses berpikir tahap pembentukan konsep yaitu dengan menyebutkan informasi yang terdapat dalam soal walaupun dengan bahasa yang kurang baik. Selain itu siswa juga mengidentifikasi masalah dengan menyebutkan hal-hal yang diketahui maupun ditanyakan. Kemudian pada tahap proses berpikir logika, siswa mengkaitkan hal-hal yang diketahui dengan ilmu pengetahuan yang telah dimiliki, sehingga dapat digunakannya untuk menentukan konsep yang terkait dengan permasalahan. Akan tetapi siswa quitter tidak melakukan pengambilan keputusan, karena tidak mengemukakan alasannya dalam menentukan konsep yang terkait dengan permasalahan. Hal ini menunjukkan bahwa mereka tidak yakin dengan keputusan yang telah diambil berkaitan dengan konsep yang terkait dengan permasalahan.

Pada langkah menyusun rencana pemecahan masalah, proses berpikir siswa adalah tidak melakukan pembentukan konsep karena tidak menyebutkan hal yang akan dilakukannya untuk menyelesaikan permasalahan. Akan tetapi, siswa telah berpikir logika karena menggunakan ilmu pengetahuan yang dimilikinya untuk menentukan bahwa hal-hal yang diketahui dalam soal telah cukup untuk menyelesaikan permasalahan. Sedangkan pada tahap terakhir siswa tidak mengambil keputusan karena tidak menyebutkan rencana atau langkah-langkah yang akan digunakan untuk menyelesaikan permasalahan.

Pada langkah menjalankan rencana pemecahan masalah, siswa tidak melakukan tahap proses berpikir pembentukan konsep, karena tidak mensubstitusikan nilai-nilai yang diketahui ke dalam aturan atau konsep yang telah ditentukan. Siswa juga tidak melakukan tahap proses berpikir logika karena tidak menjalankan rencana pemecahan masalah, hal ini juga berarti bahwa siswa juga tidak mengintegrasikan ilmu pengetahuan yang telah dimiliki ke dalam proses pemecahan masalah. Akibat selanjutnya, siswa tidak 
mengambil keputusan, karena siswa tidak menemukan hasil pemecahan masalah dan tidak mengambil keputusan dengan membuat kesimpulan dari hasil pemecahan masalah yang dilakukan.

Langkah pemecahan masalah yang terakhir adalah memeriksa kembali jawaban dalam hal ini adalah pemecahan masalah. Pada langkah ini siswa membentuk konsep bahwa pemeriksaan terhadap proses penyelesaian diperlukan untuk memastikan kebenaran hasil pemecahan serta kesimpulannya, atau siswa merasa dan menganggap tidak perlu memeriksa kembali proses pemecahan masalah. Selanjutnya karena mereka merasa tidak perlu memeriksa kembali jawaban akhirnya mereka tidak melakukan proses berpikir logika karena tidak melakukan pemeriksaan atau pengecekan pada setiap tahap proses pemecahan masalah. Akibatnya, siswa tidak mengambil keputusan dengan tepat karena tidak yakin dengan kebenaran kesimpulan yang dibuatnya.

\section{KESIMPULAN}

Berdasarkan hasil penelitian dan pembahasan di atas, proses berpikir siswa dalam memecahkan masalah perbandingan ditinjau dari Adversity Quotient (AQ) adalah sebagai berikut:

Proses berpikir siswa climber dalam memecahkan masalah perbandingan, pada langkah memahami masalah adalah membentuk konsep, berpikir logika, dan mengambil keputusan. Ketika menyusun rencana pemecahan masalah, membentuk konsep, berpikir logika, dan mengambil keputusan. Pada langkah melaksanakan rencana pemecahan masalah, mereka membentuk konsep, berpikir logika, dan mengambil keputusan. Pada langkah memeriksa kembali pemecahan masalah siswa climber membentuk konsep, berpikir logika, dan mengambil keputusan.

Proses berpikir siswa camper dalam memecahkan masalah perbandingan, pada langkah memahami masalah adalah membentuk konsep, berpikir logika, dan mengambil keputusan. Pada saat menyusun rencana pemecahan masalah, mereka membentuk konsep, berpikir logika, tetapi tidak mengambil keputusan. Pada langkah melaksanakan rencana pemecahan masalah, siswa camper membentuk konsep, berpikir logika, dan mengambil keputusan. Pada langkah memeriksa pemecahan masalah, mereka membentuk konsep, berpikir logika, tetapi tidak mengambil keputusan.

Proses berpikir siswa quitter dalam memecahkan masalah perbandingan pada langkah memahami masalah adalah membentuk konsep, berpikir logika, dan tidak mengambil keputusan. Dalam menyusun rencana pemecahan masalah, mereka tidak membentuk konsep, tetapi berpikir logika, namun tidak mengambil keputusan. pada langkah melaksanakan rencana pemecahan masalah, siswa quitter tidak membentuk 
konsep, tidak berpikir logika, dan tidak mengambil keputusan. Pada langkah memeriksa pemecahan masalah mereka tidak membentuk konsep, tidak berpikir logika, dan tidak mengambil keputusan.

Dari uraian tersebut di atas, didapat pemikiran bahwa tingkat kecerdasan adversitas atau Adversity Quotient (AQ) seorang siswa sangat mempengaruhi proses berpikirnya dalam memecahkan masalah matematika. Oleh karena itu dalam proses pembelajaran, perlu adanya pendekatan secara individual, untuk mengetahui tingkat AQ siswa. Dengan demikian guru dapat menentukan dan menerapkan model pembelajaran yang tepat pula bagi siswanya.

\section{DAFTAR PUSTAKA}

Callejo, Maria Luz \& Vila, Antoni. 2009. Approach to Mathematical Problem Solving and Students' Belief Systems: Two Case Studies. Journal of Educational Studies in Mathematics. Volum:72, page: 111-126.

Ginanjar Ary Agustian. 2001. Rahasia Sukses Membangun Kecerdasan Emosional dan Spiritual (ESQ), Jakarta: Penerbit Arya.

Huijuan, Zhou. 2009. The Adversity Quotient and Academic Performance Among College Students at St. Joseph's College Quezon City. An Undergraduate Thesis. The Faculty of The Departements of Arts and Sciences St. Joseph College Quezon City.

Herman Hudoyo. 2005. Pengembangan Kurikulum dan Pembelajaran Matematika, Malang: UM Press.

Muhtarom. 2012. Proses Berpikir Siswa Kelas IX Sekolah Menengah Pertama Dalam Memecahkan Masalah Matematika. Tesis. Program Pascasarjana Universitas Sebelas Maret. Surakarta. (tidak dipublikasikan).

Pehkonen, E. 2000. Problem Solving in Mathematics Education in Finlan. www.unige.ch/math/EnsMath/Rome2008/WG2/Papers/PEHKON.Pdf. Diunduh tanggal 23 Desember 2014.

Polya, G. (1985), How To Solve It 2nd ed. New Jersey : Princeton University Press.

Ruseffendi, E.T. 1988. Pengajaran Matematika Modern Dan Masa Kini Untuk Guru: Seri kelima. Bandung: Tarsito

Siti Nureini. 2011. Eksperimentasi Pembelajaran Matematika Dengan Model Pembelajaran Think-Talk-Write (TTW) dan Numbered Head Together (NHT) ditinjau dari Adversity Quotient Siswa Kelas VIII SMP di Surakarta. Tesis Tidak Dipublikasikan. Program Pascasarjana Universitas Sebelas Maret Surakarta.

Solso, R. L. 2007. Psykologi Kognitif Edisi Kedelapan. Penerjemah: Erlangga. Jakarta: Erlangga. 
Stoltz, Paul, G. 2000, Adversity Quotient, Turning obstacles into opportunities, New York: Willey.

Tatag Yuli Eko Siswono. 2002. Proses Berpikir Siswa Dalam Pengajuan Soal. Jurnal Nasional Matematika. Universitas Negeri Malang.

Yansen Marpaung. 1986. Proses Berpikir Siswa dalam Pembentukan Konsep Algoritma Matematis. Makalah Pidato Dies Natalis XXXI IKIP Sanata Dharma Yogyakarta, 25 Oktober 1986. 